ELORE (ISSN 1456-3010), vol. 20 - 1/2013.

Julkaisija: Suomen Kansantietouden Tutkijain Seura ry.

[http://www.elore.fi/arkisto/1_13/heikkila_rahkonen.pdf]

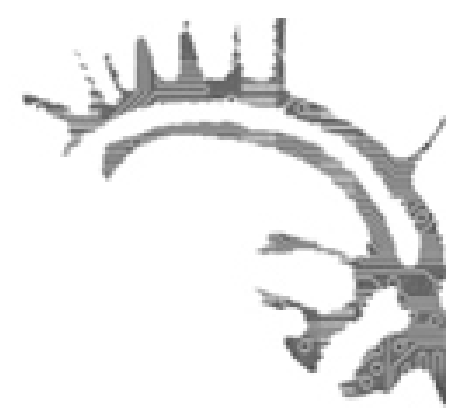

\title{
Puheenvuoro
}

\section{TUTKIMUSEETTISISTÄ KYSYMYKSISTÄ JA "SKANDAALISTA ANKKALAMMESSA"}

\author{
Riie Heikkilä \& Keijo Rahkonen
}

Vissa människor har ingen självbevarelsedrift. Till dem hör den där pyttelilla klicken av finlandssvensk överklass som alltid, med mardrömslik envetenhet, ploppar upp beredd att göra bort sig - oss! mig! - när finlandssvenskarna skall uttolkas för omvärlden.

(Ingström 2011.)

Sven-Erik Klinkmann on kirjoittanut 21-sivuisesta artikkelistamme (Heikkiä \& Rahkonen 2011) 25-sivuisen kritiikin "Forskning som förstärker stereotypisering: En kritisk diskussion om forskningsetik i Riie Heikkiläs avhandling Bättre folk, bättre smak? Suomenruotsalaisten maku ja kulttuuripääoma” (Klinkmann 2012). Se on rintamahyökkäys: Klinkmann käy taisteluun suomenruotsalaisia koskevia "stereotypioita" vastaan rakentaen karikatyyrin, olkinuken, jonka summittaisesta kritiikistä vain vaivoin tunnistamme oman tutkimuksemme. Hän esittää monentasoisia ja epäselvästi toisiinsa kietoutuvia moitteita, joissa on sekaisin puhetta etiikasta, ennakkoluuloista, faktavirheistä, tulkintavirheistä ja metodologisista preferensseistä. Seuraavassa käsittelemme esimerkkejä kustakin moitetyypistä. Klinkmann esittää myös metodologisia suosituksia, ellei peräti vaatimuksia, ja todistelee mutkikkaasti, että jokin tarkastelutapa on moraalisesti hyväksyttävämpi kuin jokin toinen, mutta niihin emme tässä ryhdy ottamaan kantaa.

1. Heti alkuun on todettava, että artikkelimme käsittelee vain yhtä suomenruotsalaisen väestön osaa. Riiie Heikkilän väitöskirjan (Heikkiä 2011) aineisto perustuu 26 eri 
alueita ja sosiaaliryhmiä edustavaan fokusryhmään ${ }^{1}$. Tämän seikan Klinkmann sivuuttaa melkein tyystin. Kyse ei siis ole siitä, annammeko osuvan kuvan suomenruotsalaisista. Kyse on siitä, annammeko osuvan kuvan tästä nimenomaisesta ryhmästä.

2. Esimerkkinä asiavirheistä Klinkman välittää informantiltaan (fokusgruppens språkrör) saamansa tiedon, että kaikki eivät asu 200-400 neliön huoneistoissa. Yksi haastateltavissa tosiaankin ilmoitti asuvansa vain 170 neliön huoneistossa. Pyydämme anteeksi harmillista epätarkkuutta, mutta se ei tietysti muuta sitä tosiasiaa, että tutkittavat asuvat väljästi, postinumeron perusteella Helsingin kantakaupungin niin sanotuilla arvoalueilla.

3. Saattaa olla, että eräät deskriptiivisiksi tarkoitetut luonnehdinnat ovat olleet epäonnistuneita siinä mielessä, että ne on voitu ymmärtää arvoarvostelmiksi. Ryhmän haastattelun alussa kerrottiin, että ryhmä oli pukeutunut kuin olisi ollut menossa cocktailtilaisuuteen:

[..] wearing clothes from several recognizable exclusive fashion houses. Before the interview started, the interviewees took a moment to check out and compliment each other on their appearances and clothes and ask where they were bought from $[.$.

(Heikkilä \& Rahkonen 2011, 148).

Lainaus oli haastattelijan neutraaliksi tarkoitettu kuvaus tilanteesta, olkoonkin että cocktailtilaisuus-luonnehdinta saattaa lukijasta riippuen vaikuttaa arvostelmalta. Siinä Heikkilän vertailuaineistona oli 25 muuta ruotsinkielistä fokusryhmähaastattelua, joista nyt puheena oleva ryhmä poikkesi sekä käyttäytymiseltään että pukeutumiseltaan drastisesti.

4. Klinkmann ja tutkittavat pitävät eräitä esittämiämme tulkintoja virheellisinä. On luonnollista, että tutkittavat ja ulkopuolinen tutkija eivät aina ole yhtä mieltä siitä, miten tutkittavien elämää ja puhetta pitää tulkita. Epätarkat tulkinnat ovat mahdollisia, mutta ne tarkentuvat tieteellisen keskustelun kautta. Sitä vastoin ei ole aiheellista vaatia, että tutkittavat saisivat lukea tutkimusraportin etukäteen.

Tutkijan pitää tehdä oikeutta tutkittaville, eikä hän ei saa tyytyä ulkokohtaiseen moralisointiin (mikäli sellaista tutkimuksessamme esiintyy, meillä on aihetta itsekritiikkiin). Klaus Mäkelän $(2008,40-47)$ mukaan tutkijan pitää arvioida aineistoaan myös tutkittavien näkökulmasta, mutta hänen ei tarvitse pitää heidän puoltaan. Tutkijan tulee raportoida tuloksensa riippumatta siitä, vahvistavatko ne vai kumoavatko ne vallitsevia käsityksiä. Vaikka voimme tuntea myötätuntoa tutkittavien puhenaista, Klinkmannin informanttia, kohtaan, on kohtuutonta vaatia, että hän saisi korjata tutkimusraporttia mieleisekseen. ${ }^{2}$

Kaikki tulkintamme eivät ehkä miellytä fokusryhmäämme, mutta kyse on tulkinnan osuvuudesta tai oikeellisuudesta, ei tutkimusetiikasta. Voisimme hyvin kuvitella, että jotkut muut tutkittavat - haastattelemamme fokusryhmät - haluaisivat hekin riitauttaa yhden ja toisen tulkinnan, mutta heillä ei ole resursseja panna liikkeelle dosenttia, joka lukee suomenruotsalaiset reviirikseen. 
5. Artikkelimme päätulos oli kuten sen tiivistimme artikkelissamme:

[..] we can argue that in this specific group there is a double-distinction: not only are Finnish speakers looked down upon and despised regardless of their class position, but the same applies to almost any other group, including even the class that the group itself belongs to (cf. Beatrix's comment about her 'tasteless' relative). 'We who live in the centre' or 'we who know how to appreciate aesthetics' are more powerful epithets than 'we who speak Swedish'. In the context of Swedish-speaking Finns, this confirms the earlier conception (Allardt and Starck 1981): this Swedish-speaking world is anything but a unit; it is composed of separate, sometimes very exclusive enclaves. But what is even more important, the unity or 'class cohesion' (cf. Ostrower 1998) of the upper class itself is based on a specific taste culture (cf. Gans 1999) as expressed by these 'ladies of taste' with their refined aestheticising of lifestyle. Moreover, most surprisingly in a Nordic welfare state like Finland, they do not hide their feelings of cultural superiority. In this sense, this case is more or less a case par excellence of Bourdieu's theory of distinction.

(Heikkiä \& Rahkonen 2011, 143.)

Mikään Klinkmannin kritiikissä ei horjuta tätä tulosta. ${ }^{3}$ Päinvastoin, ja sitä tukee myös Hufvudstadsbladetin kulttuuritoimittaja Pia Ingströmin kolumni "Anna Anka, nära dig. Pia Ingström har läst en sociologisk artikel om finlandssvenska överklassdamer" (Ingström 2011). Emme me puhuneet pahaa tutkittavista emmekä loukanneet heitä, vaan Pia Ingström. Lisäksi Klinkmannin mukaan: "Presentationen av forskningsresultatet i finlandssvensk press ledde, kan man hävda, till en präktig skandal i den så kallade ankdammen" (Klinkmann 2012, 99), mistä emme ole aiemmin kuulleet. ${ }^{4}$

Pia Ingströmin kolumni ja sen herättämä keskustelu tarjoavat hyvää lisäaineistoa tutkimukseemme. Ingström ei suinkaan moiti analyysiamme vaan tutkittavia siitä, että he naiivisti päästivät pahan sosiologin kuuntelemaan sisäryhmäpuheita. Kolumnissaan Ingström vertaa fokusryhmäämme myös ruotsalaiseen tv-sarjaan Ruotsin miljonääriäidit. Sellainen tulkinta ei mitenkään liity artikkeliimme eikä artikkelimme anna sellaiseen rinnastukseen aihetta.

6. Lopuksi: Vaikka artikkelimme konteksti oli suomenruotsalainen, missään yhteydessä artikkelissamme emme väitä, että kyse olisi vain tyypillisesti suomenruotsalaisesta ilmiöstä. Hypoteesimme on, että vastaavanlaisia ryhmiä voidaan löytää - mutatis mutandis - suomenkielisten keskuudesta. Kyse oli tapaustutkimuksesta sekä osittaisesta sattumasta, että ryhmä oli suomenruotsalainen (ja siten relevantti Riie Heikkilän väitöskirjan kannalta). Kohdeyleisömme ei liioin ollut sen paremmin suomenkielinen yleisö kuin Hufvudstadsbladetin lukijatkaan, vaan kansainvälinen sosiologinen yleisö, ja siksi julkaisimmekin artikkelin englanniksi kansainvälisellä foorumilla. ${ }^{5}$ 


\section{ViITTEeT}

1 Riie Heikkilän väitöskirjan aineisto muodostui 26 ruotsinkielestä fokusryhmähaastattelusta (joihin osallistui yhteensä 167 henkilöä) Suomen ruotsinkielisillä rannikkoseuduilla Itä-Uudeltamaalta Pohjanmaalle. Yksitoista ryhmää oli pääkaupunkiseudulta, yksitoista muista kaupungista sekä neljä pieniltä paikkakunnilta tai maaseudulta. Haastateltavat ryhmät olivat olemassa olevia niin sanottuja luonnollisia ryhmiä ja edustivat eri ikäryhmiä, sukupuolia, yhteiskuntaluokkia, ammatteja, asuinpaikkoja jne. Haastattelut käytiin ruotsiksi, ja ne nauhoitettiin ja litteroitiin. Lisäksi kaikilta haastateltavilta kerättiin taustatietolomake, johon heitä pyydettiin merkitsemään perustietojensa lisäksi siviilisääty, koulutus, oma sekä molempien vanhempien ammatti, asuinalue (postinumero) ja -muoto, asunnon koko sekä se, montako aikuista ja alaikäistä asunnossa haastatteluhetkellä asui. Kaikista haastatteluista tehtiin lisäksi kenttämuistiinpanot, joissa kuvailtiin haastattelun tunnelmaa ja sujumista. (Ks. tarkemmin Heikkilä 2011,75.)

2 Kuten Klinkmannn $(2012,99)$ näyttää tietävän, informantti otti heti Ingströmin kolumnin ilmestyttyä Hufvudstadsbladetissa meihin sähköpostitse yhteyttä pariinkin otteeseen ja esitti erilaisia vaatimuksia. Lisäksi informantti lähestyi ennen Heikkilän väitöstilaisuutta samassa asiassa muun muassa vastaväittäjä Anna Rotkirchiä.

3 Emme liioin ymmärrä, missä mielessä seuraavat Riie Heikkilän väitöskirjan tulokset "bidra till en förstärkning av stereotypiseringen" (Klinkmann 2012, 111):

Koska ruotsinkielisyydestä näyttää olevan tulossa yhä vaikeammin määriteltävä ja paikallistettava ilmiö, ehkä suomenruotsalaisuus tulisikin käsittää ennen kaikkea keskiluokkaisena kulttuurisen hyvän tahdon ilmentymänä. Kaksikielisyydestä on 2000-luvulle tultaessa tullut toivottava hyvän kulttuurisen pääoman merkki, minkä johdosta yhä useammat sekä ruotsin- että suomenkieliset koulutetut vanhemmat rekisteröivät lapsensa ruotsinkielisiksi, ilmoittavat heidät ruotsinkielisiin kouluihin ja tukevat näin mielikuvaa ruotsinkielisyydestä osana jotakin tavoiteltavaa ja distinktiivistä. Tällainen legitiimiksi koettu suomenruotsalaisuus koskettaa todellisuudessa vain pientä osaa Suomen ruotsinkielisestä väestöstä, joka on todellisuudessa monikasvoinen, fragmentaarinen ja sekä kieli-, elämäntyyli- että sosiaalisilta identifikaatioiltaan lukemattomista erilaisista osista koostuva ryhmä. (Heikkilä 2011, 58-59.)

4 Pia Ingströmin kolumnin lisäksi tiedossamme on vain Hufvudstadsbladetissa julkaistu Riie Heikkilän haastattelu "Ingen är typiskt finlandssvensk" (Bjon 2011) sekä pääkirjoitussivulla ilmestynyt Mikael Koskin kirjoitus "Det mytiska bättre folket" (Kosk 2011). Ingströmin kyseisen kolumnin kommentointi on Hufvudstadsbladetin verkkosivuilla sittemmin suljettu, joten lukijat eivät voi siihen enää tutustua. - On sinänsä mielenkiintoista, että muulla mediassa väitöskirjan tuloksiin on suhtauduttu neutraalin kiinnostuneesti eivätkä ne tietääksemme ole herättäneet mitään "skandaaleita”. 
5 Tässä valossa Klinkmannin on groteskia väittää: "Litteraturredaktören Pia Ingströms kolumnkommentar om damgruppen antyder också att det vad gäller utgångspunkten för intervjun kan ha funnits ett sensationsinriktat element som är besläktat med så kallad muckraker-journalistik" (Klinkmann 2012, 102).

\section{KirJallisuUs}

BJON, SYLVIA 2011: "Ingen är typiskt finlandssvensk. Skillnaderna mellan olika sociala och geografiska grupper är såpass stora att de drar mattan undan myten om den finlandssvenska identiteten, enligt sociologen Riie Heikkilä." - Hufvudstadsbladet 28.5.2011.

HEIKKILÄ, RIIE 2011: Bättre folk, bättre smak? Suomenruotsalaisten maku ja kulttuuripääoma. Sosiaalitieteiden laitoksen julkaisuja 2011:5. Helsinki: Helsingin yliopisto, Sosiaalitieteiden laitos.

HEIKKILÄ, RIIE \& RAHKONEN, KEIJO 2011: "It is not a Matter of Taste...': Cultural Capital and Taste among the Swedish-speaking Upper Class in Finland." - European Societies (13)1.

INGSTRÖM, PIA 2011: "Anna Anka, nära dig. Pia Ingström har läst en sociologisk artikel om finlandssvenska överklassdamer." - Hufvudstadsbladet 28.3.2011.

KLINKMANN, SVEN-ERIK 2012: "Forskning som förstärker stereotypisering: En kritisk diskussion om forskningsetik i Riie Heikkiläs avhandling Bättre folk, bättre smak? Suomenruotsalaisten maku ja kulttuuripääoma." - Elore (19)2.

KOSK, MIKAEL 2011: "Det mytiska bättre folket". - Hufvudstadsbladet 31.5.2011. MÄKELÄ, KLAUS 2008: "Etnografisen moraalin hallinnollinen ennakkosäätely."

- Kulttuurintutkimus (25)1.

Valtiotieteiden tohtori, filosofian maisteri Riie Heikkiä työskentelee tutkijatohtorina Helsingin yliopiston sosiaalitieteiden laitoksessa.

Valtiotieteiden tohtori, professori Keijo Rahkonen on Helsingin yliopiston sosiaalitieteiden laitoksen johtaja. 